the sphere of privatization. The types of administrative services of state authorities and local self-government bodies in the sphere of privatization are analyzed. The differences between "administrative services in the sphere of privatization" and "privatization services" are defined, the author's concepts are formulated. The shortcomings of the legal regulation of the provision of administrative services in the sphere of privatization and privatization services are revealed, as well as directions for its improvement.

The author concludes about the unifying features of administrative services in the field of privatization and privatization services, which are characterized by the sphere of their provision and consumers - physical and legal persons who privatize state and communal property objects, as well as persons who carry out their professional activity in the field of privatization. In view of the above, in our view, administrative services in the field of privatization can be defined as services not related to the competitive principles provided by the SPFU, its territorial subdivisions, and other bodies of state power; authorized by those state enterprises, institutions, organizations; local self-government bodies at the expense of the state or local budgets within the limits and in the manner prescribed by the legislation with the purpose of issuing an administrative act to buyers of state and communal property, as well as other entities engaged in professional activity in the field of privatization.

We propose to offer privatization services as services provided by individuals and legal entities without authority, which, in accordance with the legislation, provide consulting, informational, analytical, financial, technical, and expert activity in the field of privatization on a fee basis in accordance with the law. We consider it necessary to supplement Article 1 of the Law of Ukraine "On Privatization of State and Communal Property" with the proposed definitions of administrative services in the field of privatization and privatization services.

Key words: administrative services, privatization, public authorities, local authorities, privatization services.

DOI https://doi.org/10.33766/2524-0323.86.204-216

УДК342.922(422)

Т. В. Ющенко,

викладач кафедри цивільно-правових дисциплін Дніпровського гуманітарного університету (м. Дніпро, Україна)

e-mail: iyushchenko05@gmail.com iD https://orcid.org/0000-0002-2555-7791

\title{
ПЕРСПЕКТИВИ ВИКОРИСТАННЯ ПОЛЬСЬКОГО ДОСВІДУ АДМІНІСТРАТИВНОЇ ПРАВОСУБ'СКТНОСТІ ОРГАНІВ МІСЦЕВОГО САМОВРЯДУВАННЯ В УКРАЇНІ
}

Стаття присвячена аналізу польського досвіду адміністративної правосуб'єктності органів місцевого самоврядування. Аналізується стан нормативно-правового забезпечення функціонування органів місцевого самоврядування як суб'єктів адміністративного судочинства. Охарактеризовано адміністративно-правовий статус органів місцевого самоврядування як суб'єктів адміністративного судочинства. Визначені конкретні напрями реформування 
вітчизняного адміністративного судочинства як дієвого правозахисного інструменту в Україні.

Ключові слова: адміністративна процесуальна правосуб'єктність, адміністративне судочинство, органи місцевого самоврядування, публічна влада, територіальне самоврядування.

Постановка проблеми. Інтеграція України до європейського правового простору вимагає реформування системи законодавства на основі правових засад, які сформувалися на загальноєвропейському рівні. Розпочаті в Україні судова та реформа місцевого самоврядування, розробка нормативної бази регулювання адміністративного судочинства відбуваються із урахуванням міжнародних та європейських стандартів. Кожна європейська держава характеризується специфічними політичними та соціально-економічними ознаками, які залежать від конституції та сформованих політичних i внутрішніх соціальних відносин.

В Україні позитивний досвід функціонування різних моделей адміністративної юстиції іноземних держав впродовж багатьох років був предметом дослідження науковців та практиків, у результаті чого, як відомо, було розроблено та прийнято Кодекс адміністративного судочинства України. Найбільш доцільним видається аналіз практики тих країн, які: по-перше, досягли значних успіхів у результаті як децентралізації публічної адміністрації так і розвитку адміністративного судочинства, та, по-друге, за розмірами, кількістю населення та історією розвитку є близькими до України. Серед таких країн, у першу чергу, слід виділити Республіку Польща, тим більше, що польська модель місцевого самоврядування визнана однією з найбільш вдалих у Східній Європі. Про польський вектор подальшого реформування органів публічної адміністрації України неодноразово заявляли найвищі посадові особи держави, які зокрема зверталися до польських фахівців за отриманням практичної допомоги у проведенні реформ в Україні, у першу чергу, у сфері місцевого самоврядування, у результаті чого було розроблено відповідні законодавчі напрацювання. У зв' язку з цим й актуалізується тема дослідження.

Аналіз останніх досліджень і публікацій. Проблеми адміністративної правосуб'єктності органів місцевого самоврядування в зарубіжних країнах неодноразово ставали об'єктом дослідження багатьох учених. Про це яскраво свідчать роботи Н. Бабаченка, С. Байрака, О. Бровка, В. Дрешпака, В. Колодяжної, О. Онишка, О. Рудницької, Б. Федірка та ін. Однак, 3 урахуванням постійних змін, що відбуваються у країнах світу, проблема адміністративної процесуальної правосуб'єктності органів місцевого самоврядування потребує подальших досліджень.

Формування цілей. Метою даної статті $є$ аналіз правових засад участі органів місцевого самоврядування в адміністративному судочинстві Республіки Польща та можливості імплементації польського досвіду у вітчизняне законодавство.

Виклад основного матеріалу. Законодавче впровадження місцевого самоврядування в республіці Польща відбувалося поетапно: від нижчого до 
вищого рівнів. Ч. 1 ст. 15 Конституції встановлює, що територіальний устрій Республіки Польща забезпечує децентралізацію публічної влади. Слід зазначити, що Конституція Республіки Польща не містить ані визначення територіального самоврядування, ані більш загальної дефініції самоврядування, але подає багато складових елементів для формулювання таких дефініцій [1, с. 51]. Тобто вона визнає самоврядування, а особливо, територіальне самоврядування, - складовою публічної влади. Це твердження випливає передусім зі змісту ч. 2 ст. 16, згідно 3 якою територіальне самоврядування бере участь у здійсненні публічної влади та положень ст. 163, якими передбачено, що територіальне самоврядування виконує публічні завдання, не закріплені Конституцією або законами за іншими органами публічної влади. Важливою складовою реформи місцевого самоврядування в Польщі стало здійснення антикорупщійних заходів на публічній службі в органах місцевого самоврядування $[2,4]$.

1. Особливості місцевого самоврядування в Польщі. До основних особливостей місцевого самоврядування в Польщі можна віднести триступеневий територіальний поділ на такі структури, як-от: гміна («gmina» до компетенції якої належить вирішення публічних справ місцевого значення), повіт («powiat», який займається вирішенням справ, які виходять за межі компетенції гміни) та воєводство («województwo», які представляють уряд у відповідному регіоні та уповноважені на здійснення наглядових повноважень щодо гмін та повітів).

Головна ж відмінність у правовому регулюванні діяльності суб'єктів територіального самоврядування Польщі полягає в тому, що в Україні засади організації та діяльності органів та посадових осіб місцевого самоврядування визначено в одному нормативно-правовий акті - Законі України «Про місцеве самоврядування в Україні», натомість у Республіці Польща основними законодавчими актами у цій сфері є три окремі закони: «Про самоврядування гмінне» (1990р.)., «Про самоврядування повітове» (1998р.), «Про самоврядування воєводське» (1998р.). Органи самоврядування, не підпорядковані центральному уряду, діють самостійно і незалежно та підлягають лише державному правовому нагляду. Основні засади здійснення адміністративного нагляду за діяльністю органів місцевого самоврядування викладені в законі Республіки Польща «Про воєводу і урядову адміністрацію у воєводстві» від (2009 р.).

Згідно з положеннями частини 3 ст. 164 Конституції Республіки Польща гміна виконує всі завдання територіального самоврядування, не закріплені за іншими одиницями територіального самоуправління. Згідно 3 положеннями ст. 22 закону «Про самоврядування гмінне», внутрішня організація та порядок організації діяльності гміни визначаються їі статутом, який підлягає опублікуванню в урядовому щоденнику воєводства. Завдання гміни поділяються на власні ѝ делеговані (доручені урядовою адміністрацією). Так законом може бути покладено на гміну обов'язок виконання делегованих завдань, які належать до компетенції урядової адміністрації, а також щодо організації підготовки і проведення чергових 
виборів та референдумів [3, с. 35-36]. Завдання, віднесені до компетенції урядової адміністрації, гміна може виконувати також на підставі домовленості з органами цієї адміністрації. Делегування гміні завдань урядової адміністрації обов'язково супроводжується виділенням коштів у розмірі, необхідному для їх виконання.

Загальновизнано, що польське місцеве самоврядування на рівні гмін (громад) відповідає стандартам Європейської хартії місцевого самоврядування, яка стверджує: «Місцеве самоврядування означає право i спроможність органів місцевого самоврядування в межах закону здійснювати регулювання і управління суттевою часткою суспільних справ, які належать до їхньої компетенції, в інтересах місцевого населення». Польське законодавство містить досить широкий спектр інструментів щодо залучення громадськості щодо вирішення суспільних справ на місцевому рівні [12].

Законодавство Польщі своєрідно підійшло до визначення статусу та порядку діяльності тих формувань, які, згідно із законодавством України, визнані органами самоорганізації населення. Польське законодавство називає їх «допоміжними органами», які створюються в «допоміжних одиницях». Ст. 5 Закону Польщі «Про самоврядування гмінне» передбачено, що самоврядна громада - гміна - «може утворити допоміжні одиниці: сільські округи, райони, селища тощо». Допоміжні органи не мають статусу юридичних осіб, і тому їх керівники здійснюють свою діяльність самостійно на підставі доручення, виданого правлінням гміни.

Наступною одиницею локального самоврядування є повіт, до повноважень якого належить надання лише тих послуг, які не могли бути забезпечені на місцевому рівні. Крім того, на повітовому рівні самоврядування здійснюється координація головних контрольних функцій, які здійснюються іншими службами (поліція, пожежна служба, ветеринарна інспекція тощо), проте підпорядковані голові його адміністрації. Відповідно до ст. ст. 8, 9 Закону «Про самоврядування повітове» (1998 р.) жителі повіту беруть участь в загальному голосуванні чи за посередництвом органів гміни. Органами повіту є рада повіту (приймає рішення і здійснює контроль та території повіту, з урахуванням положень про повітові референдуми) та правління (виконавчий орган) повіту [5, с. 97]. Повітам можуть делегуватися окремі повноваження воєводств (як законом, так і договором). Воєводський рівень, на відміну від двох перших, носить дуалістичний характер. Завдання його самоврядних структур мають в основному регіональний характер i полягають у створенні сприятливих умов для розвитку регіону та надання громадських послуг у його межах. Урядові ж структури покликані зміцнювати структуру місцевого самоврядування і забезпечувати цілісність держави.

2. Адміністративно-правовий статус органів місцевого самоврядування в Польщі. У Республіці Польща діє Кодекс адміністративного провадження від 14 червня 1960 р., який регулює зокрема провадження в органах публічної адміністрації у належних до компетенції цих органів індивідуальних справах, що вирішуються адміністративними рішеннями та провадження у 
справах скарг і пропозицій (ч. VIII) в державних органах, органах одиниць територіального самоврядування. Кодексом визначено, що скарги подаються в апеляційні колегії самоврядування (ст. 17), Голові Ради Міністрів або відповідним міністрам (ст. 18) й визначено процедуру подання і розгляду скарг (ч. ІІ-Х). Під вжитим в Кодексі адміністративного провадження терміном «органи публічної адміністрації розуміються міністри, центральні органи урядової адміністрації, воєводи, діючі від їхнього або від власного імені місцеві органи урядової адміністрації, органи одиниць територіального самоврядування [6, с. 63]. До останніх належать: органи гміни, повіту, воєводства, об'єднання гмін, об'єднання повітів, війт, бурмістр (президент міста), староста, маршалек воєводства та керівники служб, інспекцій та службовці, що діють від імені війта,бурмістра, старости або маршалка воєводства, а крім того самоврядні апеляційні колегії (ст. 5 Кодексу).

У зв'язку з наведеним, як позитивний досвід польського суспільства слід відзначити розвинений і досконалий інститут досудової адміністративної процедури або провадження у справах на дії чи бездіяльність публічної адміністрації. На жаль, в умовах сучасної України такий спеціалізований адміністративно-процедурний кодекс ще не прийнято. Аналізовані проблеми врегульовуються низкою розрізнених адміністративно-правових актів -законами України «Про звернення громадян» [7], «Про ліцензування видів господарської діяльності» [8], «Про основні засади державного нагляду (контролю) у сфері господарської діяльності» [9], «Про охорону навколишнього природного середовища» [10], «Про соціальні послуги» [11] та ін., а також різними підзаконними нормативно-правовими актами. Зазначені нормативно-правові акти деякою мірою усувають законодавчі прогалини щодо процедурного забезпечення прав і свобод за законних інтересів фізичних і юридичних осіб у процесі квазісудової діяльності, однак безсистемність і вузький предмет регулювання залишає за межами правового впорядкування вагому частину важливих суспільних відносин щодо забезпечення прав i свобод людини i громадянина публічною адміністрацією.

Разом з тим спрямованість на забезпечення прав і законних інтересів осіб у відносинах із державою та їі органами є визначальною ознакою розвитку законодавства в демократичних країнах. Одна 3 найважливіших гарантій цього - чітка регламентація процедурного аспекту відносин особи і влади. За таких умов державний службовець чи службовець органу місцевого самоврядування діє не свавільно, а керуючись чітко встановленим порядком. Це, по-перше, забезпечує рівність осіб перед законом, адже до всіх однопорядкових справ застосовується однакова процедура, а по-друге, існування законодавчо встановленої процедури $є$ вихідною точкою для здійснення контролю, зокрема судового, за законністю діяльності органів влади.

За переконанням польського вченого С. Завадського, між адміністративною процедурою й контролем суду за ії реалізацією існує дуже 
тісний зв'язок, що, на думку вченого, слугує достатнім аргументом на користь поєднання їх у рамках одного комплексного акту. Так у результаті судового рішення, що стосується питання про законність оскарженого управлінського акту, справа може бути знову переглянута органом державного управління i, таким чином, судовий розгляд стає окремою і специфічною стадією адміністративного процесу. Також він звертав увагу на той факт, що адміністративний орган, який розглядає справу, не зможе не зважати на ті наслідки, які приносить в адміністративний процес інститут судового контролю. Так само й суддя, що розглядає спір про законність адміністративного рішення, не може не мати перед очима всієї адміністративної процедури. Таким комплексним актом, який поєднав регламентування як адміністративної процедури, так і судового контролю, що здійснюється судом за іiі законністю, став зазначений вище Кодекс адміністративного провадження Республіки Польща. У державах із континентальною системою права державний нагляд за діяльністю в сфері місцевого самоврядування визнається наслідком принципу правової держави. Це означає, що муніципалітети здійснюють свої дії в межах законів і можуть бути обмежені тільки за допомогою законів. Відносно держави вони мають власні права, які вони можуть захищати в суді. Як відомо, рівень демократії у будь-якій країні визначається наявністю сильної та незалежної судової гілки влади. Основним критерієм визначення таких ознак $є$ наявність дієвої та повноцінної системи адміністративного судочинства. Розгляд адміністративних спорів у Польщі знаходиться за межами компетенції загальних судів, він побудований за континентальною моделлю адміністративної юстиції.

Конституція Республіки Польща в питаннях судової влади передбачає відносну чіткість викладення відповідних норм і докладно фіксує не тільки судовий устрій країни, а й компетенцію вищих судових органів. Ч. 1 ст. 175 Конституції встановлено, що правосуддя в Польській Республіці здійснюють Верховний Суд, загальні суди, адміністративні суди, а також військові суди. 3 наведеного випливає, що система адміністративних судових органів у Польщі функціонує за принципом розумного і виваженого використання спеціалізації судочинства в рамках загальної юрисдикції. Особливість же статусу адміністративних судів порівняно із загальними полягає в незалежності від Міністерства юстиції країни. Для вирішення адміністративних справ законодавець створив особливий юрисдикційний орган - Вищий адміністративний суд, який знаходиться в столиці країни (м. Варшава) і має декілька відділень, розташованих у ряді польських воєводств [13, с. 76]. Його рішення мають обов'язкову силу для відповідного органу державного управління при повторному адміністративному розгляді справи. Нагляд за його діяльністю здійснює Верховний Суд Польщі. Він має право розглядати рішення Верховного Суду Польщі у порядку надзвичайної ревізії, протесту міністра юстиції й голови Верховного Суду Польщі, а також приймати постанови, що містять відповідні юридичні питання, що стосуються його функцій. 
Згідно з положеннями ст. 184 Конституції Республіки Польща Вищий Адміністративний Суд, а також інші адміністративні суди здійснюють у сфері, визначеній у законі, контроль за діяльністю публічної адміністрації. Цей контроль включає також винесення судових рішень про відповідність законам постанов органів територіального самоврядування та нормативних актів місцевих органів урядової адміністрації. Розмежування компетенції судових органів обумовлюється потребою найкращої організації судової влади, щоб створити для осіб, які потребують судового захисту, найбільш сприятливі умови для участі в судочинстві, для залучення всіх заінтересованих осіб і доказів по справі. Проте, незважаючи на позитивні наміри законодавця, інколи під час визначення предметної підсудності адміністративних справ, залишається більше запитань, ніж відповідей, окремі положення Кодексу адміністративного судочинства (далі - КАС) України не враховують усіх нюансів відносин, що виникають на підставі цих норм, великою мірою мають бланкетний характер, інколи характеризуються недосконалістю.

3. Перспективи запровадження польського досвіду адміністративного судочинства. В Україні вже не перший рік триває дискусія з приводу необхідності прийняття окремого матеріального закону, який би чітко врегульовував правила адміністративних процедур для органів державної влади, місцевого самоврядування та їх посадових осіб. Взаємозв'язок між адміністративною процедурою та судовим адміністративним контролем $€$ очевидним: на підставі Кодексу адміністративного судочинства України адміністративні суди мають можливість перевіряти, наскільки правильно, законно та обгрунтовано суб'єкти владних повноважень, до яких належать органи місцевого самоврядування, реалізовують свої повноваження, тоді як власне здійснення органами місцевого самоврядування має відбуватися саме за приписами закону про адміністративну процедуру. Таким чином, закон про адміністративну процедуру встановлює правила поводження органів місцевого самоврядування у взаєминах із людиною, а за Кодексом адміністративного судочинства України суд перевіряє, наскільки активність представника публічної влади була правильною та відповідала засадам законодавства.

В Республіці Польща діє комплексний акт, який поєднав регламентування як адміністративної процедури, так і судового контролю, що здійснюється судом за ії законністю - Кодекс адміністративного провадження Республіки Польща.

Зважаючи на позитивний польський досвід існування комплексного закону та виходячи з того, що ідея прийняти окремий адміністративний процедурний кодекс в Україні впродовж багатьох років не увінчується успіхом, виходом з ситуації може бути доповнення існуючої редакції КАС України розділами, які врегульовуватимуть взаємини людини з публічною владою на етапі досудового провадження. Це забезпечить єдність термінології, процедур, принципів та спростить розуміння правил 
прийняття зокрема органами місцевого самоврядування тих чи інших рішень у зносинах з приватними особами.

Відповідно до положень ст. 191 Конституції Республіки Польща, органи територіального самоврядування $є$ суб'єктами звернення до Конституційного трибуналу. У даному контексті звертає на себе увагу той факт, що за новою редакцією Закону України «Про Конституційний Суд України» органи місцевого самоврядування не є суб'єктами права на конституційне подання або конституційне звернення (ст. ст. 52, 54). Раніше таке право було гарантовано ст. 41 зазначеного закону, згідно з якою органи місцевого самоврядування наділялися повноваженням на пряме звернення до єдиного органу конституційної юрисдикції для одержання відповідних висновків у справах щодо офіційного тлумачення Конституції і законів України.

У відповідності до ч. 3 ст. 8 Закону України «Про Конституційний Суд України» Конституційний Суд України не розглядає питання щодо відповідності законам України актів органів місцевого самоврядування, що $\epsilon$ цілком виправданим застереженням законодавця з огляду на наявність іншого механізму здійснення судового контролю за нормотворчістю органів влади на місцях.

Характерною особливістю польської адміністративної юстиції є те, що для звернення із скаргою до воєводського адміністративного суду обов'язковою умовою $\epsilon$ процедурний іï розгляд двома інстанціями публічної адміністрації і лише у випадку, коли громадянин незадоволений рішенням апеляційної процедурної інстанції, він має право звернутись до воєводського адміністративного суду [14, с. 211]. Наявність умови обов'язкового розгляду скарги або звернення громадянина в порядку адміністративної процедури органами публічної адміністрації перед зверненням до адміністративного суду $\epsilon$ своєрідним фільтром від надходження до цього суду незначних та дріб' язкових справ.

Наведені положення закріплені в ст. 52 Закону «Про провадження в адміністративних судах», згідно з якими скарга до адміністративного суду подається лише після використання способів оскарження позивачем в процесі у відповідному органі у справі, якщо скаргу не вносить прокурор, уповноважений з прав людини або уповноважений з прав дитини [15, с. 41]. Під використанням способів оскарження належить розуміти ситуацію, за якої сторона не наділена жодними способами оскарження, такими як скарга, оскарження або передбачене законом клопотання про повторний перегляд справи. Такий підхід дозволяє уникнути надходження великої кількості справ до судів, оскільки з усієї кількості справ, які надходять до вищих адміністративних органів, що переглядають рішення органів нижчого рівня, лише близько 10 \% подаються до адміністративних судів першої інстанції.

У ст. 22 Кодексу про адміністративне провадження встановлено підвідомчість або предметну компетенцію органів, які вповноважені розглядати та вирішувати спори про компетенцію. Зокрема передбачено, що адміністративним судом вирішуються спори про компетенцію, які 
виникають між органами одиниць територіального самоврядування та між органами територіального самоврядування й місцевими органами урядової адміністрації. У § 3 зазначеної норми вказано, що з пропозицією про розгляд спору адміністративним судом можуть звертатись: сторона, орган одиниці територіального самоврядування або інший орган публічної адміністрації, що залишився в спорі; міністр, відповідальний за справи публічної адміністрації; міністр, відповідальний за справи юстиції; Генеральний Прокурор; Уповноважений з прав людини [16].

Висновок. Підсумовуючи викладене, можемо зробити висновок, що наявні відмінності в правовому регулюванні участі органів місцевого самоврядування в адміністративному судочинстві Польщі та України зумовлені різним рівнем розвитку місцевого самоврядування в даних державах та характерними особливостями їхніх правових систем. Утім, євроінтеграційні прагнення України можуть мати перспективи лише за умови проведення активної пошукової та нормотворчої роботи 3 імплементації законодавства України до законодавства країн Європейського Союзу, однією 3 яких є Республіка Польща, наближенням національної системи права, правової доктрини, судової практики до європейських стандартів.

Як показав польський досвід реформування системи місцевого самоврядування, розширення повноважень органів місцевої влади супроводжувалося посиленням адміністративного та судового контролю за законністю здійснення цими органами публічного управління.

У зв'язку з наведеним, впровадження реформи децентралізації влади в Україні, спрямованої на посилення ролі місцевого самоврядування, має кореспондуватися 3 процесами щодо удосконалення законодавства, яке регулює досудову адміністративну процедуру розгляду справ органами публічної адміністрації та модернізацією відповідно до викликів часу процесуального законодавства, яке регламентує участь органів місцевого самоврядування в адміністративному судочинстві

\section{Використані джерела:}

1. Федірко Б. О. Розподіл повноважень в системі місцевого самоврядування республіки Польща. Соціально-економічні проблеми сучасного періоду України. 2016. Вип. 4. С. 50-53.

2. Державна антикорупційна політика і запобігання та протидія корупції на публічній службі в органах державної влади і органах місцевого самоврядування: монографія / автор. кол.; В.В. Василевич, Т.Е. Василевська, В.Ф. Нестерович, Е.В. Расюк, А.В. Савченко, В.Л. Федоренко (кер.) та ін.; за ред. проф. Ю.В. Ковбасюка і проф. В.Л. Федоренка. К.: Видавництво Ліра-К, 2016. 524 с.

3. Колодяжна В. Роль органів місцевого самоврядування (ОМСВ) у розвитку інформаційного транскордонного співробітництва України та Республіки Польща. Правова інформатика. 2011. № 3-4. С. 34-39. 
4. Нестерович В.Ф. Конституційно-правове регулювання лобіювання у Литві, Польщі та Угорщині: уроки для України. Проблеми правознавства та правоохоронної діяльності. 2010. № 1. С. 29-37.

5. Дрешпак В. М., Бабаченко Н. В. Комунікативна діяльність служб зі зв'язків 3 громадськістю органів місцевого самоврядування міст республіки Польща. Держава та регіони. Серія : Соціальні комунікації. 2018. № 3. С. 94-102.

6. Онишко О. Б. Вплив глобалізації на місцеве самоврядування в Польщі. Науковий Вісник Львівського державного університету внутрішніх справ. серія юридична. 2017. Bun. 4. C. 59-68.

7. Про звернення громадян: Закон України від 2 жовтня 1996 р. № 393. URL.: https://zakon2.rada.gov.ua/laws/show/393/96-вр.

8. Про ліцензування видів господарської діяльності : Закон України від 2 березня 2015 р. № 222-VIII. URL.: https:/ / zakon.rada.gov.ua/go/222-19.

9. Про основні засади державного нагляду (контролю) у сфері господарської діяльності: Закон України від 5 квітня 2007 p. № 877-V. URL.: https:/ / zakon.rada.gov.ua/go/877-16.

10. Про охорону навколишнього природного середовища: Закон України від 25 червня 1991 р. № 1264-XII. URL.: https:/ / zakon.rada.gov.ua/go/1264-12.

11. Про соціальні послуги : Закон України від 17 січня 2019 р. № 966-IV URL.: https:/ / zakon.rada.gov.ua/go/2671-19.

12. Нестерович В.Ф. Вплив громадськості на прийняття нормативно-правових актів: проблеми конституційної теорії та практики: Монографія. Луганськ: РВВ ЛДУВС ім. Е.О. Дідоренка, 2014. 736 с.

13. Бровко О. В. Історія формування місцевого самоврядування в Польщі Науковий часопис НПУ імені М. П. Драгоманова. Серія 22 : Політичні науки та методика викладання соціально-політичних дисциплін. 2017. Вип. 21. С. 74-79.

14. Рудницька О. Реформування місцевого самоврядування в Україні та Польщі: порівняльний аналіз. Intermarum: історія, політика, культура. 2016. Вип. 3. С. 208-220.

15. Байрак С. О. Особливості взаємодії органів місцевого самоврядування й державної влади Республіки Польща. Політикус. 2017. Вип. 1. С. 39-43.

16. Кодекс адміністративного судочинства України від 6 липня 2005 року. № 2747-IV. URL.: http:/ / www.zakon.rada.gov.ua/go/2747-15.

\section{References}

1. Fedirko B. O. Rozpodil povnovazhen' v systemi mistsevoho samovryaduvannya respubliky Pol' shcha [Distribution of powers in the system of local self-government of the Republic of Poland. Socio-economic problems of the modern period of Ukraine]. Sotsial' no-ekonomichni problemy suchasnoho periodu Ukrayiny. 2016. Vol. 4. p. 50-53.

2. Derzhavna antykoruptsiina polityka i zapobihannia ta protydiia koruptsii na publichnii sluzhbi v orhanakh derzhavnoi vlady i orhanakh mistsevoho [State anticorruption policy and prevention and counteraction of corruption in the public service in public authorities and local self-government bodies] / avtor. kol.; V. V. Vasylevych, T. E. Vasylevs' ka, V. F. Nesterovych, E.V. Rasyuk, A.V. Savchenko, V. L. Fedorenko (ker.) ta in.; za red. prof. YU.V. Kovbasyuka i prof. V. L. Fedorenka. K.: Vydavnytstvo Lira-K, 2016. 524 p.

3. Kolodyazhna V. Rol' orhaniv mistsevoho samovryaduvannya (OMSV) u rozvytku informatsiynoho transkordonnoho spivrobitnytstva Ukrayiny ta Respubliky Pol' shcha [The Role of Local Self-Government Bodies (OMSV) in the Development of Information Transborder 
Cooperation between Ukraine and the Republic of Poland]. Pravova informatyka. 2011. Vol. 34. p. 34-39.

4. Nesterovych V.F. Konstytutsiyno-pravove rehulyuvannya lobiyuvannya u Lytvi, Pol' shchi ta Uhorshchyni: uroky dlya Ukrayiny [Constitutional and legal regulation of lobbying in Lithuania, Poland and Hungary: lessons for Ukraine]. Problemy pravoznavstva ta pravookhoronnoyi diyal' nosti. 2010. Vol. 1. p. 29-37.

5. Dreshpak V. M., Babachenko N. V. Komunikatyona diyal' nist' sluzhb zi zv'yazkiv $z$ hromads' kistyu orhaniv mistsevoho samovryaduvannya mist respubliky Pol' shcha [Communicative activity of public relations services of local authorities of the cities of the Republic of Poland. State and regions]. Derzhava ta rehiony. Seriya: Sotsial' ni komunikatsiyi. 2018. Vol. 3. p. 94-102.

6. Onyshko O. B. Vplyv hlobalizatsiyi na mistseve samovryaduvannya v Pol' shchi [The Impact of Globalization on Local Government in Poland. Scientific herald of Lviv State University of Internal Affairs]. Naukovyy visnyk L' vivs' koho derzhavnoho universytetu vnutrishnikh sprav. seriya yurydychna. 2017. Vol. 4. p. 59-68.

7. Pro zvernennya hromadyan: Zakon Ukrayiny vid 2 zhovtnya 1996 r. № 393 [On Citizens' Appeal: Law of Ukraine dated October 2, 1996 No. 393]. Verkhovna Rada of Ukraine. URL: https:/ / zakon2.rada.gov.ua/laws/show/393/96-vr.

8. Pro litsenzuvannya vydiv hospodars' koyi diyal' nosti: Zakon Ukrayiny vid 2 bereznya 2015 r. № 222-VIII [On licensing of types of economic activity: Law of Ukraine dated March 2, 2015, No. 222-VIII]. Verkhovna Rada of Ukraine. URL: https://zakon.rada.gov.ua/go/222-19.

9. Pro osnovni zasady derzhavnoho nahlyadu (kontrolyu) u sferi hospodars' koyi diyal' nosti: Zakon Ukrayiny vid 5 kvitnya 2007 r. № 877-V [On the Basic Principles of State Supervision (Control) in the Field of Business Activity: Law of Ukraine of April 5, 2007 No. 877-V]. Verkhovna Rada of Ukraine. URL. : https:/ / zakon.rada.gov.ua/go/877-16.

10. Pro okhoronu navkolyshn' oho pryrodnoho seredovyshcha: Zakon Ukrayiny vid 25 chervnya 1991 r. № 1264- XII [On Environmental Protection: Law of Ukraine dated June 25, 1991 No. 1264-XII]. Verkhovna Rada of Ukraine. URL.: https:/ / zakon.rada.gov.ua/go/1264-12.

11. Pro sotsial' ni posluhy: Zakon Ukrayiny vid 17 sichnya 2019 r. № 966-IV [On Social Services: Law of Ukraine dated January 17, 2019 No. 966-IV]. URL.: https:/ / zakon.rada.gov.ua/go/2671-19.

12. Nesterovych V.F. Vplyv hromads' kosti na pryynyattya normatyono-pravovykh aktiv: problemy konstytutsiynoyi teoriyi ta praktyky: Monohrafiya [The Impact of the Public on the Adoption of Regulatory Acts: Problems of Constitutional Theory and Practice: Monograph]. Luhans' k: RVV LDUVS im. E.O. Didorenka, 2014. 736 p.

13. Brovko O. V. Istoriya formuvannya mistsevoho samovryaduvannya v Pol' shchi [The History of the Formation of Local Self-Government in Poland]. Naukovyy chasopys NPU imeni M. P. Drahomanova. Seriya 22: Politychni nauky ta metodyka vykladannya sotsial' nopolitychnykh dystsyplin. 2017. Vol. 21. p. 74-79.

14. Rudnyts' ka O. Reformuvannya mistsevoho samovryaduvannya v Ukrayini ta Pol' shchi: porivnyal' nyy analiz [Reforming Local Self-Government in Ukraine and Poland: A Comparative Analysis]. Intermarum: istoriya, polityka, kul' tura. 2016. Vol. 3. p. 208-220.

15. Bayrak S. O. Osoblyvosti vzayemodiyi orhaniv mistsevoho samovryaduvannya y derzhavnoyi vlady Respubliky Pol' shcha [Features of the interaction of local government and state authorities of the Republic of Poland]. Politykus. 2017. Vol. 1. p. 39-43. 
16. Kodeks administratyvnoho sudochynstva Ukrayiny vid 6 lypnya $2005 \mathrm{r}$. № 2747-IV [The Code of Administrative Legal Proceedings of Ukraine of July 6, 2005, No. 2747-IV]. Verkhovna Rada of Ukraine. URL. : http://www.zakon.rada.gov.ua/go/2747-15.

Стаття надіӥшла до редколегї 12.04.2019

Ющенко Т. В., преподаватель кафедры гражданско-правовых дисциплин Днепровского гуманитарного университета (г. Днепр, Украина)

\section{ПЕРСПЕКТИВЫ ИСПОЛЬЗОВАНИЯ ПОЛЬСКОГО ОПЫТА АДМИНИСТРАТИВНОЙ ПРАВОСУБЪЕКТНОСТИ ОРГАНОВ МЕСТНОГО САМОУПРАВЛЕНИЯ В УКРАИНЕ}

Статья посвящена анализу польского опыта административной правосубъектности органов местного самоуправления. Анализируется состояние нормативно-правового обеспечения функционирования органов местного самоуправления как субъектов административного судопроизводства. Охарактеризован административно-правовой статус органов местного самоуправления как субъектов административного судопроизводства. Определены конкретные направления реформирования отечественного административного судопроизводства как действенного правозащитного инструмента в Украине.

Ключевые слова: административная процессуальная правосубъектность, административное судопроизводство, органы местного самоуправления, публичная власть, территориальное самоуправление.

Yushchenko T., teacher department of civil law disciplines Dnieper humanitarian university (Dnipro, Ukraine)

\section{PROSPECTS OF USING THE POLISH EXPERIENCE OF ADMINISTRATIVE LEGAL PERSONALITY OF LOCAL SELF-GOVERNMENT BODIES IN UKRAINE}

The article is devoted to the analysis of the Polish experience of the administrative legal personality of local self-government bodies. The state of the normative and legal maintenance of functioning of the bodies of local self-government as subjects of administrative legal proceedings is analyzed. The administrative and legal status of local self-government bodies as subjects of administrative legal proceedings is described. The concrete directions of reforming the domestic administrative justice as an effective human rights instrument in Ukraine are determined.

The author states that Ukraine's integration into the European legal space requires the reform of the legal system on the basis of legal principles that have been formed at the European level. The judicial and local self-government reform launched in Ukraine, the 
development of a normative framework for the regulation of administrative proceedings is taking place in accordance with international and European standards. Each European state is characterized by specific political and socio-economic features, which depend on the constitution and the prevailing political and internal social relations.

It is concluded that the existing differences in the legal regulation of the participation of local self-government bodies in the administrative proceedings of Poland and Ukraine are due to different levels of development of local self-government in these states and the specific features of their legal systems. However, the European integration aspirations of Ukraine can have prospects only if active search and standard-setting work is underway on the implementation of Ukrainian legislation in the legislation of the European Union countries, one of which is the Republic of Poland, approximation of the national system of law, legal doctrine, judicial practice to European standards.

Key words: administrative procedural legal personality, administrative justice, local self-government bodies, public authority, territorial self-government. 